\title{
Comportamiento de morteros de escoria activada alcalinamente con adición de fibras de carbón
}

\section{Carbon fibre-reinforced, alkali-activated slag mortars}

\author{
J. S. Alcaide ${ }^{(*)}$, E. G. ${ }^{\text {a }}$ Alcocel(*), F. Puertas $^{(* *)}$, R. Lapuente ${ }^{(*)}$ y P. Garcés ${ }^{(*)}$
}

Recepción/Received: 8-I-07

Aceptación/Accepted: 12-IV-07

RESUMEN

Se ha estudiado el efecto de la incorporación de fibras de carbón en el comportamiento mecánico, estabilidad de volumen y nivel de corrosión de la armadura en morteros de escorias activadas alcalinamente (AAS). Se evalúa la influencia de las fibras de carbón en el comportamiento de morteros alcalinos en comparación con el efecto que producen en morteros de Portland (CP). Los ensayos mecánicos y de estabilidad de volumen se han realizado según lo establecido en la norma UNE que los regula. Se ha utilizado la técnica de la Resistencia a la Polarización para determinar la velocidad de corrosión del acero embebido en las muestras estudiadas. Como consecuencia del estudio realizado, se ha podido concluir que la adición de fibras de carbón a morteros de AAS y CP no mejora las características resistentes de los mismos. En relación con la estabilidad de volumen, la incorporación de fibras de carbón a los morteros de AAS, preparados con una relación líquido/sólido de 0,5 , reduce alrededor del $50 \%$ su retracción al secado. Los estudios de corrosión han demostrado que en condiciones de carbonatación, los morteros de AAS con fibras de carbón incrementan el nivel de corrosión del acero embebido en los mismos; mientras que mejora sensiblemente el comportamiento de los morteros AAS con un $1 \%$ de fibra de carbón frente a la corrosión ante el ataque por cloruros.

Palabras clave: escoria activada alcalinamente, mortero, fibra de carbono, propiedades mecánicas, corrosión.
SUMMARY

The paper describes the effect of carbon fibre on alkaliactivated slag mortar (AAS) mechanical strength, volume stability and reinforcing steel corrosion, compared to its effect on the same properties in Portland cement (PC) properties. Mechanical strength and volume stability tests were performed as set out in the respective Spanish UNE standards. The corrosion rate of steel embedded in the specimens studied was determined from Polarization Resistance analysis. One of the findings of the study performed was that carbon fibre failed to improve AAS or CP mortar strength. As far as volume stability is concerned, the inclusion of carbon fibres in AAS with a liquid/solid ratio of 0.5 reduced drying shrinkage by about 50\%. Studies showed that in the presence of carbonation, steel corrosion reached higher levels in carbon-fibre reinforced AAS mortars; the inclusion of $1 \%$ carbon fibre improved corrosion resistance perceptibly in these same mortars, however, when exposed to chloride attack.

Keywords: alkali-activated slog, mortar, carbon fibre, mechanical properties, corrosion.

\footnotetext{
(*) Universidad de Alicante (Alicante, España).

(**) Instituto de Ciencias de la Construcción Eduardo Torroja (CSIC), Madrid (Madrid, España).
} 


\section{INTRODUCCIÓN}

La necesidad de alcanzar los requisitos establecidos en el Protocolo de Kioto y en otras normativas medioambientales y energéticas ha hecho que desde hace varias décadas el estudio y desarrollo de cementos alternativos al cemento Portland sea una línea de investigación preferente y de elevado interés científico y tecnológico a escala mundial. Los estudios enmarcados en esta línea están orientados a desarrollar nuevos conglomerantes en cuya fabricación no se emitan gases contaminantes y se obtengan a través de procesos que no requieran un elevado consumo energético.

Dentro de estos materiales alternativos se encuentran aquéllos que proceden de la activación alcalina de subproductos industriales tales como las escorias de horno alto y/o las cenizas volantes. Estos cementos alcalinos se obtienen por la mezcla de dichos subproductos y disoluciones fuertemente alcalinas. Estos cementos se caracterizan por presentar unas elevadas prestaciones mecánicas y no requerir en su elaboración los elevados consumos energéticos que son inherentes al proceso de fabricación de los cementos Portland.

Las escorias de horno alto son materiales conocidos en el ámbito de la construcción y utilizados como adición activa para la elaboración de distintos cementos normalizados y hormigones. Los cementos de escoria y de horno alto poseen algunas propiedades y características que los hacen especialmente útiles cuando se desean bajos calores de hidratación y elevadas resistencia a los sulfatos y al agua de mar.

El principio en el que se basa la activación alcalina de escorias fue propuesto inicialmente por Purdon (1) en 1949, pero fue en los años sesenta cuando Glaukhovsky et al. (2-3) desarrollaron los primeros cementos y morteros de escorias activadas alcalinamente. A partir de los años noventa el interés por los cementos activados alcalinamente fue creciendo en la Europa occidental y en otros países como China, India, Japón, USA.

Los cementos y hormigones de escorias activadas alcalinamente con waterglass se caracterizan por desarrollar unas resistencias comparables a las del cemento Portland. Diferentes autores han comprobado la elevada resistencia química de estos cementos y hormigones frente al ataque por sulfatos y al agua de mar (4-5), a la difusión de cloruros (6), a los medios ácidos (7), a ciclos hielo-deshielo (8-9), a altas temperaturas (10), etc. Este óptimo comportamiento durable está asociado a la naturaleza de los productos de hidratación (11-12), especialmente el gel CSH que se forma en estas pastas, y a la baja porosidad y permeabilidad de estos hormigones (13). Sin embargo, los cementos y hormigones de escorias

\section{INTRODUCTION}

In recent decades, the need to meet the requirements laid down in the Kyoto Protocol and other environmental and energy legislation has made the study and development of alternatives to Portland cement a priority line of research and an issue of intense scientific and technological interest world-wide. Such studies are geared to developing new binders whose manufacture involves neither the emission of pollutant gases nor high energy consumption.

Among the alternative binders under study are industrial by-products such as blast furnace slag and/or fly ash, which when mixed with highly alkaline solutions yield cementitious materials. These cements, characterized by high mechanical strength, can be manufactured with much smaller amounts of energy than Portland cement.

Blast furnace slag is a familiar construction material, for it is used as an active addition to make certain standardized cements and concretes. The properties and characteristics of slag and blast furnace cements make them particularly useful in situations requiring low heat of hydration and high sulphate and seawater resistance.

The principle on which slag alkali activation is based was initially proposed by Purdon (1) in 1949, but it was not until the nineteen sixties that Glaukhovsky et al. (2-3) developed the first alkali-activated slag cements and mortars. Interest in alkali activated cements began to grow in the nineteen nineties in Western Europe and countries such as China, India, Japan and the USA.

Waterglass-activated slag cements and concretes are characterized by their ability to develop strength comparable to the strength of Portland cement. Several authors have proven that these cements and concretes are highly resistant to sulphate and sea water attack (4-5), chloride diffusion (3-4), acid media (7), freeze-thaw cycles (8-9), high temperatures (10) and so on. Their optimal durability is associated with the nature of their hydration products (11-12), particularly the CSH gel formed in these pastes, along with their low porosity and permeability (13). However, alkali-activated slag cements and concretes obtained with sodium silicate activators (also known as waterglass) exhibit dry shrinkage rates 
activadas alcalinamente obtenidos cuando el activador es un silicato sódico (también denominado waterglass) desarrollan unas retracciones al secado hasta cuatro veces superiores a los correspondientes de cemento Portland (14). Esta desventaja tecnológica afecta mucho a sus posibilidades de aplicación.

En trabajos previos $(15,8)$ se ha comprobado que la incorporación de fibras acrílicas (en un porcentaje de hasta un $1 \%$ en peso de ligante) no reduce dicha retracción, mientras que las de polipropileno (incorporadas en igual proporción) lo reducían en un $25 \%$. Recientemente, también se ha estudiado el efecto de fibras de vidrio alcali-resistente (AR) especialmente diseñadas para reducir la retracción al secado en sistemas cementantes (16). Los resultados obtenidos han mostrado que dichas fibras reducen hasta un $20 \%$ la retracción al secado.

Por otra parte, en los últimos años ha ido incrementándose el uso de la fibra de carbón en el campo de la construcción. A pesar del elevado precio de las mismas, se encuentran usos específicos donde las superiores características de la fibra compensarían dicho coste: alta durabilidad, bajo peso, resistencia a la erosión, baja abrasión, baja permeabilidad o apantallamiento de campos electromagnéticos (17). Con respecto a su influencia en las características resistentes y en la durabilidad de morteros y hormigones de cemento Portland se ha demostrado la mejora de las mismas en los conglomerados que contienen adición-sustitución de bajas cantidades de fibras de carbón cortas (18-19).

Las fibras de carbón, tal y como es conocido, son muy durables en medios alcalinos (20). Teniendo en cuenta sus interesantes propiedades físico-químicas, el objetivo de este trabajo es ver el efecto de su incorporación sobre las características resistentes, la retracción al secado y el nivel de corrosión que presenta la armadura embebida en morteros fabricados con cemento alcalino y fibras de carbón.

\section{PARTE EXPERIMENTAL}

\subsection{Materiales utilizados y preparación de morteros}

En el presente trabajo se ha utilizado una escoria de horno alto y un cemento Portland tipo I 52.5 R. La composición química de estos materiales se muestra en la Tabla 1. La superficie específica de la escoria y del cemento Portland eran de 325 y $515,5 \mathrm{~m}^{2} / \mathrm{kg}$, respectivamente, y el contenido en fase vítrea de la escoria de horno alto es del 99\%. La escoria de horno alto se activó alcalinamente con una disolución de waterglass $\left(\mathrm{Na}_{2} \mathrm{O} \cdot \mathrm{nSiO}_{2} \cdot \mathrm{mH}_{2} \mathrm{O}+\mathrm{NaOH}\right)$ que contenía un $4 \%$ de $\mathrm{Na}_{2} \mathrm{O}$, con respecto a la masa de escoria y una relación $\mathrm{SiO}_{2} / \mathrm{Na}_{2} \mathrm{O}$ de 1,18 . up to four times greater than observed in Portland cement (14). This drawback has a clear impact on their applicability.

Previous studies $(15,8)$ showed that while such shrinkage is not reduced by the inclusion of acrylic fibres (up to $1 \%$ by weight of binder), it is $25 \%$ lower when polypropylene fibres are added (in the same proportion). The effect of alkali-resistant (AR) fibreglass specially designed to reduce drying shrinkage in cementitious systems was also the object of a recent study (16). The findings showed that such fibres reduce drying shrinkage by up to $20 \%$.

The use of carbon fibre in construction, in turn, has likewise grown in recent years. The high cost of this type of fibre is offset, in certain specific uses, by its excellent characteristics: long durability, light weight, erosion resistance, low abrasion, low permeability and electromagnetic shielding (17). Furthermore, Portland cement mortar and concrete strength and durability have been shown to improve when the binders contain small amounts of short carbon fibres as additions or substitutions (18-19).

Carbon fibre as it is presently known is more durable in alkaline environments (20). In light of the excellent physical and chemical properties of this material, the present study aimed to determine its effect on alkaline cement mortar strength and drying shrinkage and the corrosion of the embedded reinforcement.

\section{EXPERIMENTAL}

\subsection{Materials used and preparation of mortars}

The chemical composition of the blast furnace slag and type I 52.5R Portland cement used in this study are given in Table 1. The specific surface for the slag and the Portland cement were 325 and $515.5 \mathrm{~m}^{2} / \mathrm{kg}$, respectively; the vitreous phase content of the former was $99 \%$. The slag was alkali-activated with a waterglass solution $\left(\mathrm{Na}_{2} \mathrm{O} \cdot n \mathrm{niO}_{2} \cdot \mathrm{mH}_{2} \mathrm{O}+\mathrm{NaOH}\right)$ containing $4 \% \mathrm{Na}_{2} \mathrm{O}$ by slag mass and a $\mathrm{SiO}_{2} / \mathrm{Na}_{2} \mathrm{O}$ ratio of 1.18 . 
Se prepararon morteros de escoria activada alcalinamente (AAS) y de cemento Portland (CP) con una relación (en peso) arena/escoria $=3$. En el caso de los morteros de AAS, se prepararon probetas con dos relaciones líquido/sólido: 0,56 y 0,5; en los morteros de CP únicamente se prepararon morteros con relación agua/cemento de 0,50 . Se incorporó un porcentaje de fibra de carbón entre 1 y $3 \%$ en peso de ligante.

En este trabajo se ha utilizado un solo tipo de fibra de carbón de uso general suministrada por Donacarbo con diámetro de $13 \mu \mathrm{m}$ y diferentes longitudes: (FCP) polvo de $130 \mu \mathrm{m}$ y (FC3) de $3 \mathrm{~mm}$. Es una fibra de carbón fabricada a partir de breas de alquitrán de carbón. En la Figura 1 se muestra el aspecto general de la fibra FCP. La composición elemental de la fibra se muestra en la Tabla 2.

El análisis elemental de materiales carbonosos consiste básicamente en una combustión flash de las muestras objeto de estudio. Con la información que aporta la técnica, es posible realizar una cuantificación de la cantidad de carbono, hidrógeno, nitrógeno y azufre que contiene una muestra. Los análisis se llevan a cabo, sometiendo a la muestra a una combustión controlada en atmósfera de oxígeno a alta temperatura, la cual oscila entre $9500^{\circ} \mathrm{C}$ y $1.100{ }^{\circ} \mathrm{C}$. Los gases producidos durante la combustión se encuentran completamente oxidados en forma de $\mathrm{CO}_{2}$, $\mathrm{H}_{2} \mathrm{O}$, NO y $\mathrm{SO}_{2}$, respectivamente. Dichos gases son trasladados a un cromatógrafo de gases, donde a través de una columna cromatográfica y un detector de conductividad térmica son separados y cuantificados. Por medio de esta técnica podemos conocer la composición másica de carbono $\left(\mathrm{CO}_{2}\right)$, nitrógeno (NO), hidrógeno $\left(\mathrm{H}_{2} \mathrm{O}\right)$ y azufre
Alkali-activated slag (AAS) and Portland cement (PC) mortars were prepared with a binder/sand ratio (by weight) of 3. Two liquid/solid ratios were used to make the AAS mortar specimens: 0.56 and 0.5; all the PC specimens were made with mortars having a water/cement ratio of 0.50 .

A single type of standard 13- $\mu \mathrm{m}$ carbon fibre, supplied by Donacarbo, was used in this study. The lengths used were: (CFP) 130- $\mu \mathrm{m}$ powder and 3-mm (CF3). This fibre is made from coal tar pitch. Figure 1 contains a microphotograph of PCF fibre and whose elementary composition is given in Table 2.

In carbonaceous materials, elementary analysis is generally performed by flash combustion. The information afforded by this technique suffices to quantify the amount of carbon, hydrogen, nitrogen and sulphur contained in the sample. The analysis consists in subjecting the sample to controlled combustion at a temperature ranging from 950 to $1,100{ }^{\circ} \mathrm{C}$ in an atmosphere of pure oxygen. The gases produced during combustion, completely oxidized to $\mathrm{CO}_{2}, \mathrm{H}_{2} \mathrm{O}, \mathrm{NO}$ and $\mathrm{SO}_{2}$, are carried to a gas chromatographer where they are separated and quantified by means of a chromatographic column and a thermal conductivity detector. This technique gives the composition by mass of the carbon $\left(\mathrm{CO}_{2}\right)$, nitrogen (NO), hydrogen $\left(\mathrm{H}_{2} \mathrm{O}\right)$ and sulphur $\left(\mathrm{SO}_{2}\right)$ contained in a carbonaceous material. The method does not, however, quantify the oxygen,

Tabla 1 / Table 1

Análisis químico de la escoria de horno alto y de cemento Pórtland Cheminal analysis of furnace slag and Portland cement

\begin{tabular}{|l|c|c|c|c|c|c|c|c|c|c|}
\hline & $\begin{array}{c}\mathbf{C a O} \\
(\%)\end{array}$ & $\mathbf{S i O}_{\mathbf{2}}$ & $\mathbf{A l}_{\mathbf{2}} \mathbf{O}_{\mathbf{3}}$ & $\mathbf{M g O}$ & $\mathbf{F e}_{\mathbf{2}} \mathbf{O}_{\mathbf{3}}$ & $\mathbf{S O}_{\mathbf{3}}$ & $\mathbf{S}^{2}-$ & $\mathbf{N a}_{\mathbf{2}} \mathbf{O}$ & $\begin{array}{c}\text { P. F.* } \\
\text { L.I. } *\end{array}$ & $\begin{array}{c}\text { R. I.** } \\
\text { I.R. } * *\end{array}$ \\
\hline Escoria / Slag & 41.00 & 35.34 & 13.65 & 4.11 & 0.39 & 0.06 & 1.91 & 0.01 & 2.72 & 0.64 \\
\hline Cemento / Cement & 61.51 & 19.76 & 3.66 & 2.07 & 4.73 & 3.03 & - & 0.12 & 2.52 & 0.66 \\
\hline
\end{tabular}

* P.F. Pérdida al fuego / L.I. Loss on ignition; ** R.I. Residuo insoluble / I.R. Insoluble residue.

Tabla 2 / Table 2

Análisis elemental de las fibras utilizadas

Elementary analysis of the fibre used

\begin{tabular}{|c|c|c|c|c|}
\hline \multirow{2}{*}{$\begin{array}{c}\text { Muestra } \\
\text { Sample }\end{array}$} & \multicolumn{4}{|c|}{ Análisis elemental (\% en peso) / Elementary analysis (in \% by weight) } \\
\hline & C & H & $\mathbf{N}$ & $(S+0)_{\text {dif }}$ \\
\hline FCP & 87.46 & 0.68 & 1.04 & 10.57 \\
\hline FC3 & & & & \\
\hline
\end{tabular}


$\left(\mathrm{SO}_{2}\right)$ que contiene un material carbonoso. Sin embargo, no podemos cuantificar el oxígeno, que generalmente se calcula por diferencia (O = 100-C-H-N-S-Cenizas).

Se realizaron ensayos previos para valorar la estabilidad de estas fibras en medios fuertemente básicos asimilables a los utilizados en la preparación de los cementos de escorias activadas alcalinamente. Estos ensayos consistieron en introducir las fibras, filamentos y polvo, en disoluciones de $\mathrm{NaOH}(\mathrm{pH}=13.6)$ y waterglass $\left(\mathrm{Na}_{2} \mathrm{SiO}_{3}+\mathrm{NaOH}, \mathrm{pH}=\right.$ $13,1)$, y extraer dichos materiales a determinadas edades ( 2 y 4 meses). La estabilidad de las fibras fue evaluada a través de espectroscopía de absorción infrarroja por Transformada de Fourier (FIIR). Estos estudios demostraron la estabilidad de dichas fibras.

Para conseguir una adecuada dispersión de la fibra de 3 $\mathrm{mm}$, se ha utilizado como dispersante metilcelulosa en una proporción del 0,4\% sobre el peso del conglomerante, que se incorpora junto con el agua de amasado. La incorporación de los materiales carbonosos se ha realizado, por seguridad, mezclándolos con el agua de amasado. La Figura 2 muestra el aspecto general de un mortero de AAS con un 3\% de adición de FC3. En esta figura se puede observar que, a pesar de todo, la homogeneización del sistema no era muy buena, así como la adherencia fibra-matriz.

\subsection{Ensayos}

Los morteros preparados fueron sometidos a los siguientes ensayos.

\subsubsection{Resistencias mecánicas a compresión y flexotracción}

Se han fabricado probetas prismáticas de 4 × 4 × $16 \mathrm{~cm}$ mediante compactación mecánica en dos capas. Las probetas se han curado bajo agua siendo ensayadas a las siguientes edades de curado: 2, 28 y 120 días. Los

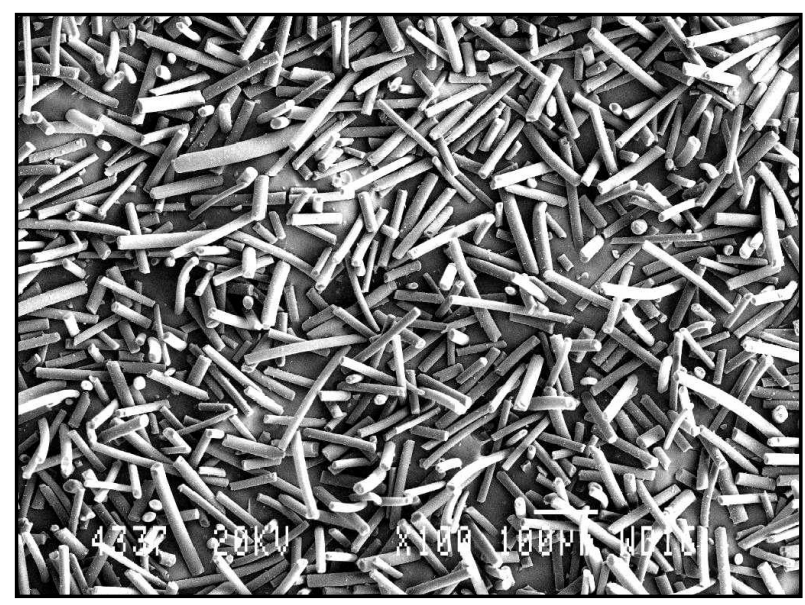

Figura 1. Imagen de microscopía electrónica de la fibra FCP. Figure 1. Electron microscope image of CFP fibre. which is generally calculated as the remainder $(O=$ $100-C-H-N-S-a s h)$.

Preliminary tests were conducted to assess fibre stability in highly basic environments, comparable to those generated to prepare alkali-activated slag cements. These tests consisted in keeping the fibre, filaments or powder, in $\mathrm{NaOH}(\mathrm{pH}=13.6)$ and waterglass $\left(\mathrm{Na}_{2} \mathrm{SiO}_{3}+\mathrm{NaOH}\right.$, $p H=11$.) solutions for two or four months. When evaluated for stability after extraction with Fourier transform infrared spectroscopy (FTIR), the fibres were found to be stable.

Methylcellulose, added to the mixing water in a proportion of $0.4 \%$ of the weight of the binder, was used to ensure suitable dispersion of the 3-mm fibre. For reasons of safety, the carbonaceous materials were also added to the mixing water. Figure 2 depicts an AAS mortar to which 3\% CF3 was added. The figure shows that, despite the precautions, system homogenization and the fibre-matrix bond were imperfect.

\subsection{Tests}

The mortars prepared were subjected to the following tests.

\subsubsection{Mechanical (compressive and flexural) strength}

The $4 \times 4 \times 16-\mathrm{cm}$ prismatic specimens made for the tests were cast in two lifts and mechanically consolidated. The specimens were cured in water and tested 2, 28 and 120 days after casting. The strength tests were

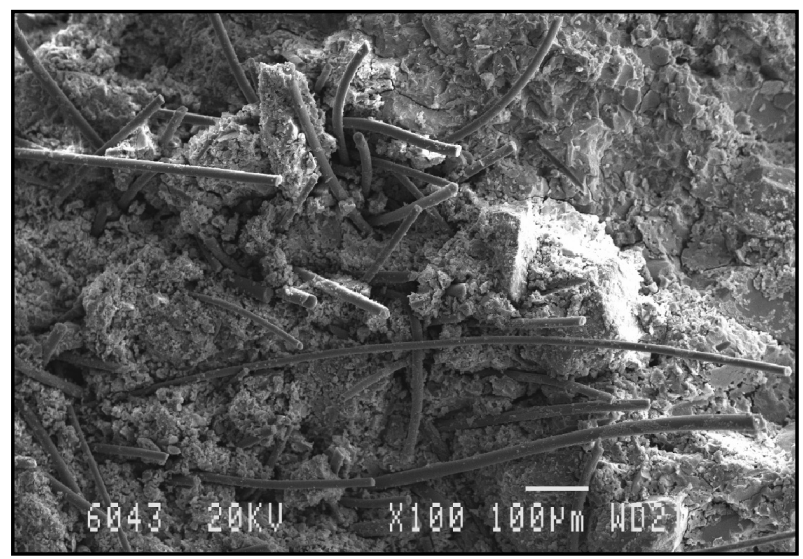

Figura 2. Imagen de microscopía electrónica de mortero de AAS con $3 \%$ de FC3.

Figure 2. Electron microscope image of AAS mortar with 3\% CF3. 
ensayos mecánicos se han realizado en condiciones de laboratorio según lo establecido en la norma EN-196-1 (21). Estos ensayos se han realizado sobre los morteros de CP con diferentes porcentajes de adición de FCP y agua/ligante de 0,5. Estos ensayos también se han realizado sobre morteros de AAS con diferentes porcentajes de adición FCP y FC3 y disolución activadora/ligante de 0,56.

\subsubsection{Determinación de la retracción al secado}

Se determinó la retracción, de acuerdo a la norma UNE 80-112-89 (22), en probetas de mortero prismáticas de $2,5 \times 2,5 \times 28,7 \mathrm{~cm}$ de AAS y CP. Los morteros se prepararon de acuerdo a la norma UNE-EN 196-1 (21).

En estos estudios de retracción se decidió emplear únicamente la fibra de mayor longitud (la fibra FC3, $3 \mathrm{~mm}$ ) para comprobar su efecto reductor de la retracción.

Tras un curado previo de $24 \mathrm{~h}$ en cámara de humedad al 99\% de HR y Ta de $21 \pm 2{ }^{\circ} \mathrm{C}$, las probetas desmoldadas se conservaron al $50 \%$ de HR y una Ta de $21 \pm 2{ }^{\circ} \mathrm{C}$. Las medidas se realizaron después de las primeras 24 en estas condiciones y durante 60 días. Estos ensayos se han realizado sobre los morteros de $\mathrm{CP}$ con porcentajes entre el 1-3\% de adición de FC3 y agua/ligante de 0,5. Estos ensayos también se han realizado sobre morteros de AAS con porcentajes entre el 1-3\% de adición de FC3 y disolución activadora/ligante de 0,5 y 0,56.

\subsubsection{Ensayos de corrosión}

Se han fabricado probetas prismáticas de morteros de AAS de dimensiones $80 \times 55 \times 20 \mathrm{~mm}$ y distintos porcentajes 0,1 y $3 \%$ de adición de FC3, con relación disolución activadora/escoria de 0,56 (se ha añadido metilcelulosa al $0,4 \%$ en peso de ligante para facilitar la dispersión de la fibra). Cada probeta contiene dos electrodos cilíndricos de $8 \mathrm{~mm}$ de diámetro de acero al carbono y un contra-electrodo de grafito en el medio. El espesor de recubrimiento resultante es de $6 \mathrm{~mm}$. La Figura 3 muestra un esquema de las probetas utilizadas para las medidas de corrosión. El área expuesta del acero ha sido de $16,3 \mathrm{~cm}^{2}$. En cada probeta se ha medido el valor de velocidad de corrosión instantánea, $\mathrm{I}_{\text {corr, }}$ para cada electrodo de acero y se ha tomado como resultado para la misma el valor medio de ambos. La duración del proceso de medida ha sido el tiempo suficiente hasta conseguir valores de $\mathrm{I}_{\text {corr }}$ estables.

Una vez curadas las probetas durante 7 días en agua a $20{ }^{\circ} \mathrm{C}$, se han sometido a dos tipos de ataque: proceso de carbonatación acelerada (con $\mathrm{CO}_{2}$ puro y $70 \%$ de $\mathrm{HR}$ ) e inmersión parcial en disolución de $\mathrm{NaCl}=0,5 \mathrm{M}$ que simula el agua de mar. Todos estos ensayos se han realizado a una temperatura de $20^{\circ} \mathrm{C}$. conducted under laboratory conditions as specified in European standard EN-196-1 (21) on PC mortars with different percentages of CFP and a water/binder ratio of 0.5 , as well as on AAS mortars with different percentages of CFP and CF3 and an activating solution/binder ratio of 0.56 .

\subsubsection{Drying shrinkage}

Drying shrinkage was determined as specified in Spanish standard UNE 80-112-89 (22) on $2.5 \times 2.5 \times 28.7-\mathrm{cm}$ prismatic AAS and PC mortar specimens. The mortars were prepared to Spanish standard UNE 196-1 (21).

Only the longer fibre (CF3, $3 \mathrm{~mm}$ ) was used in these shrinkage studies to ascertain its shrinkage-reducing effect.

After preliminary curing for $24 \mathrm{~h}$ in a moist cabinet kept at $99 \% \mathrm{RH}$ and a temperature of $21 \pm 2{ }^{\circ} \mathrm{C}$, the samples were demoulded and stored at $50 \% \mathrm{RH}$ and a $\mathrm{T}$ of $21 \pm$ $2{ }^{\circ} \mathrm{C}$. Measurements were taken after the first 24 hours in the latter conditions and daily for the following 60 days. These tests were conducted on PC mortars with 1$3 \%$ CFP and a water/binder ratio of 0.5 , as well as on AAS mortars with 1-3\% CF3 and activating solution/binder ratios of 0.5 and 0.56 .

\subsubsection{Corrosion tests}

AAS mortar prismatic specimens measuring $80 \times 55 \times 20$ $\mathrm{mm}$ were prepared with three different percentages of CF3 (0, 1 and 3\%) and an activating solution/slag ratio of $0.56(0.4 \%$ by binder weight of methylcellulose was added to facilitate fibre dispersion). Each specimen contained two 8-mm diameter carbon steel cylindrical electrodes and a graphite counter electrode in the medium. The resulting cover measured $6 \mathrm{~mm}$. A diagram of the specimens used for corrosion measurements is given in Figure 3. The area of steel exposed was $16.3 \mathrm{~cm}^{2}$. The instantaneous corrosion rate $\left(I_{\text {corr }}\right)$ was measured in the two steel electrodes and the mean value used for analysis. The duration of the measuring process was the time required to obtain stable $I_{\text {corr }}$ values.

After curing for seven days in water at $20^{\circ} \mathrm{C}$, the specimens were subjected to two types of attack: accelerated carbonation (with pure $\mathrm{CO}_{2}$ and $70 \% \mathrm{RH}$ ) and partial immersion in a $0.5-\mathrm{M} \mathrm{NaCl}$ solution to simulate seawater. All these trials were conducted at $20^{\circ} \mathrm{C}$. 


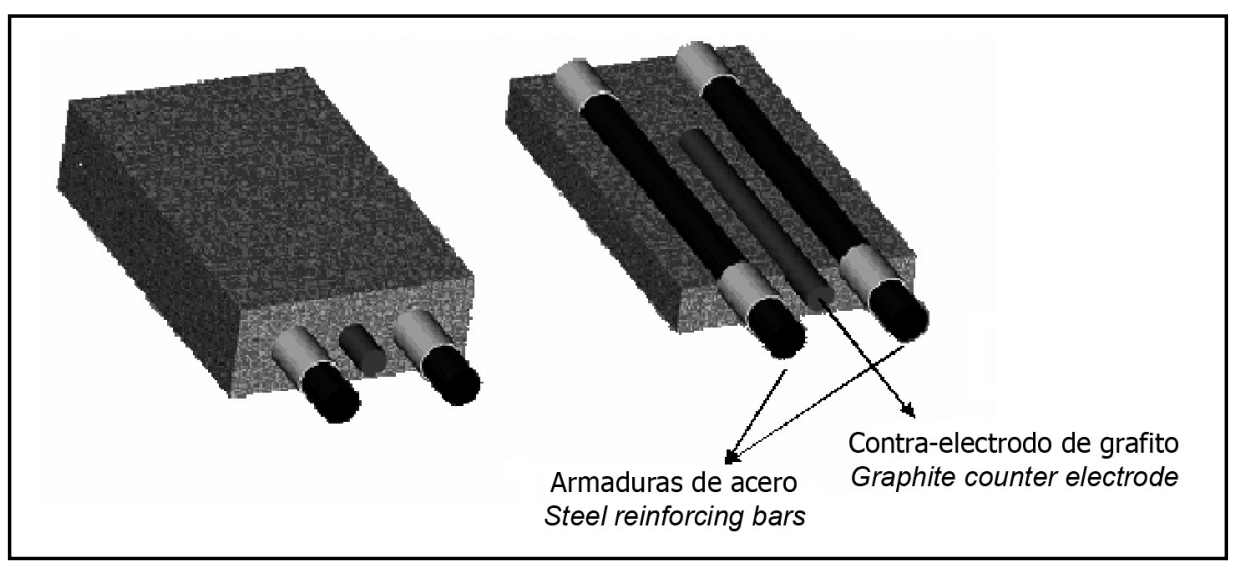

Figura 3. Esquema de las probetas utilizadas para las medidas de corrosión.

Figure 3. Diagram of the specimens used for corrosion measurements.

La mitad de las probetas fabricadas se someten a un proceso de carbonatación acelerada introduciéndolas en un desecador de vidrio en cuyo fondo hay una disolución de glicerina que permite mantener una humedad del $70 \%$, por encima de la disolución se coloca una bandeja perforada que recibe a las probetas evitando el contacto de éstas con la disolución. Para comprobar el estado de carbonatación de las probetas, se utiliza el método de la fenolftaleína. Para ello se corta una rebanada de $1 \mathrm{~cm}$ de espesor de las probetas prismáticas de $80 \times 20 \times 20 \mathrm{~mm}$ y sobre ella se vierte unas gotas de fenolftaleína.

La otra mitad de las probetas, fabricadas para el estudio del ataque por cloruros, se han introducido en recipientes con una disolución de $\mathrm{NaCl}$ 0,5 M que simula el agua de mar. Las probetas están parcialmente cubiertas por el agua, dejándose en su parte superior dos centímetros de las mismas libres, para evitar el contacto directo de los electrodos con los cloruros. A lo largo de toda la experiencia se intenta que el nivel de la disolución se mantenga constante y se evitará que la superficie libre de los electrodos se vea afectada por la corrosión, lo que se consigue protegiéndoles, en sus extremos libres, con una capa de vaselina, que se repondrá tantas veces cuantas sean necesarias para evitar la corrosión de los electrodos.

La técnica electroquímica usada para medir la velocidad de corrosión instantánea, $\mathrm{I}_{\text {corr }}$ ha sido la técnica de la Resistencia a la Polarización, $\mathrm{R}_{\mathrm{p}}$; a través de la bien conocida fórmula de Geary y Stern (23) $I_{\text {corr }}=B / R_{p}$. $I_{\text {corr }}$ se ha calculado considerando la constante $B=26$ $\mathrm{mV}$ para acero corroído o $52 \mathrm{mV}$ para acero pasivado (24). Durante todo el tiempo del experimento se ha medido periódicamente $R_{p}$ y el potencial de corrosión $\left(E_{\text {corr }}\right)$. Al final del mismo, se ha determinado para cada electrodo la pérdida de peso (pérdida gravimétrica). Todos los valores de potencial están referidos al electrodo de calomelanos saturado (ECS). Se ha usado un Potenciostato-Galvanostato 362 EG\&G. Los valores de
Half of the specimens manufactured were subjected to accelerated carbonation by placing them in a glass desiccator containing a glycerine solution at the bottom to keep the humidity at $70 \%$. The specimens were set on a perforated tray positioned over the solution to prevent direct contact between the specimens and the solution. The phenolphthalein method was used to verify specimen carbonation. This consisted in pouring a few drops of phenolphthalein on the $1-\mathrm{cm}$ thick slices of mortar removed from each $80 \times 20 \times 20-\mathrm{cm}$ prismatic specimen.

The other half of the specimens, manufactured to study chloride attack, were placed in receptacles containing a $0.5-\mathrm{M} \mathrm{NaCl}$ solution designed to simulate seawater. The specimens were only partially submerged, up to $2 \mathrm{~cm}$ from the top, to prevent any direct contact between the electrodes and the chlorides. An attempt was made throughout the experiment to keep the water level constant and prevent the exposed area of the electrodes from corroding. The latter was achieved by protecting the free end with a layer of Vaseline, which was replenished as necessary to prevent electrode corrosion.

Polarization Resistance, $R_{p}$ and the well-known Geary Stern (23) formula, $I_{\text {corr }}=B / R_{p}$, were used to calculate instantaneous corrosion, $I_{\text {corr }}$. The value used for constant $B$ was $26 \mathrm{mV}$ for corroded steel and $52 \mathrm{mV}$ for passivated steel (24). $R_{p}$ and the corrosion potential ( $E_{\text {corr }}$ ) were measured periodically throughout the experiment. At the end of the trial, weight loss (gravimetric loss) was found for each electrode. All the potential values were referred to the saturated calomel electrode (ECS). The measurements were taken with an EG\&G 362 Potentiostat-Galvanostat. The $I_{\text {corr }}$ values were calculated as the mean of four measurements (two specimens, two electrodes each). The electrochemical loss estimated by integrating 
$\mathrm{I}_{\text {corr }}$ han sido calculados como el valor medio entre cuatro medidas (dos probetas, dos electrodos cada una). La pérdida electroquímica estimada de la integración de las curvas de $\mathrm{I}_{\text {corr }}$ en función del tiempo ha sido comparada con la pérdida gravimétrica correspondiente (obtenida directamente mediante pesada). La buena concordancia obtenida entre ambas valida el valor de B empleado.

\section{RESULTADOS Y DISCUSIÓN}

\subsection{Resistencias mecánicas}

En la Figura 4 se muestran los valores de resistencia a compresión en función del tiempo de curado de morteros de AAS fabricados con adición de distintos porcentajes de fibra de carbón en polvo, FCP $(0,1,3$ y $5 \%$ en peso de ligante). En las figuras aparece en línea discontinua el intervalo de confianza del 95\%. El intervalo de confianza implica que en él se encuentra el verdadero valor del experimento, nunca conocido exactamente, con un grado prefijado de seguridad.

Tal y como se puede observar en la Figura 4, se produce un aumento de la resistencia a compresión con el tiempo para todos los porcentajes de fibra adicionados. Sin embargo, la adición de la fibra en polvo FCP no mejora, pero tampoco modifica significativamente el comportamiento mecánico del patrón, a excepción del mortero con el 5\% de FCP. En el caso de los morteros con $1 \%$ de $\mathrm{FCP}$, el comportamiento es prácticamente idéntico al del patrón. Se observa que conforme aumenta el porcentaje de adición de FCP, la resistencia mecánica disminuye. Así, para los morteros fabricados con $1 \%$ de FCP, la disminución de resistencia mecánica registrada es de un 3\%, siendo dicha disminución de un $6 \%$ y un $10 \%$ para los fabricados con un $3 \%$ y $5 \%$ de $\mathrm{FCP}$, respectivamente.

Si se comparan estos resultados con los obtenidos en los morteros de CP que incorporan el mismo tipo de fibra (ver Figura 5), se observa que dichas fibras tienen un efecto negativo sobre la evolución resistente de dichos morteros, especialmente cuanto el porcentaje de fibra supera el $1 \%$ de ligante. Esta pérdida de resistencia es significativa, suponiendo una disminución del $17 \%$, respecto del patrón, para porcentajes en fibra del 3 y $5 \%$. Este comportamiento puede ser explicado por la dificultad en la correcta homogenización del sistema que provoca heterogeneidades en los morteros por el exceso de fibra.

La Figura 6a muestra los valores de resistencia a flexión en función del tiempo de curado de morteros de AAS fabricados con adición de distintos porcentajes, 0,1 y $3 \%$ the $I_{\text {corr }}$ vs time curves was compared to the respective gravimetric loss (obtained by directly weighing the samples). The close agreement between the two confirmed the validity of the $B$ value used.

\section{RESULTS AND DISCUSSION}

\subsection{Mechanical strength}

The compressive strength of AAS mortars made with 0 , 1, 3 and $5 \%$ (by binder weight) carbon fibre powder, CFP, is plotted against curing time in Figure 4. The dotted lines denote the $95 \%$ confidence intervals. The confidence interval is the range of values within which the actual experimental value, which is never known with absolute certainty, lies.

As the graph shows, compressive strength rose over time in all the mortars, regardless of the percentage of fibre added. The addition of carbon fibre powder did not improve, nor - with the exception of the mortar containing 5\% CFP- did it significantly change mechanical performance as compared to the control. Indeed, behaviour was practically identical in mortars containing $0 \%$ and $1 \%$ CFP. Mechanical strength was observed to decline as the percentage of CFP rose. For mortars made with $1 \%$ CFP, strength was found to slide by $3 \%$, while that decrease was 6 and 10\%, respectively, for mortars made with 3 and 5\% CFP.

When this same type of fibre was added to PC mortars (see Figure 5), it also had an adverse effect on strength development, particularly when the percentage of fibre was over $1 \%$ of the binder weight. Strength loss was significant, at $17 \%$, when the percentage of fibre added was 3 or 5\%. This behaviour may be explained by the imperfect dispersion of the fibre in the system, which would lead to pockets of excess fibre in the mortar.

The flexural strength of AAS mortars made with 0, 1 and 3\% 3-mm carbon fibre (CF3) is plotted against curing time in Figure 6a. In this case the samples were prepared with 
de fibra de carbón de $3 \mathrm{~mm}$ de longitud (FC3). En este caso las muestras fueron preparadas con una adición sobre el peso de cemento de $0,4 \%$ de metilcelulosa con el objeto de mejorar la dispersión de las fibras en la pasta. Con este tipo de fibra sólo se ha trabajado hasta el 3\% debido a la dificultad de obtener morteros homogéneos con mayores porcentaje de fibra, incluso utilizando metilcelulosa.

En principio cabría esperar que la adición de fibras de esta longitud implicara un aumento de la resistencia a flexión. No es así, e incluso disminuye al aumentar el porcentaje de fibra. Por lo que hay que plantearse que existe la posibilidad de que la fibra se curve disminuyendo su interacción con la pasta, por tanto, la resistencia intrínseca del conjunto. Aun así esta disminución no se puede considerar significativa.

La Figura $6 \mathrm{~b}$ muestra los valores de resistencia a compresión en función del tiempo de curado de morteros de AAS fabricados con adición de distintos porcentajes, 0, 1 y $3 \%$ de FC3 y adición de $0,4 \%$ de metilcelulosa. El comportamiento observado es similar al registrado en flexotracción. Se produce una disminución, aunque de nuevo no estadísticamente significativa, de las características resistentes de estos morteros con la adición de estas fibras respecto al patrón.

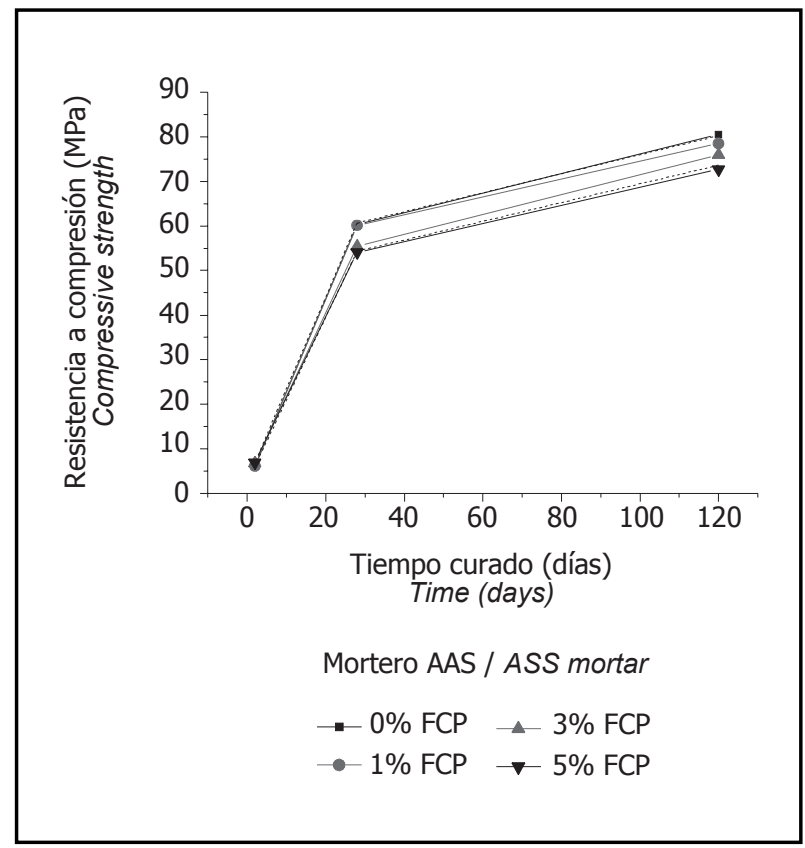

Figura 4. Resistencia a compresión en función del tiempo de curado de morteros de AAS fabricados con adición de distintos porcentajes de FCP. (Las líneas discontinuas representan el intervalo de confianza de $95 \%$.)

Figure 4. Compressive strength versus curing time in AAS mortars made with different percentages of CFP.

(The dotted lines denote the $95 \%$ confidence intervals.)
$0.4 \%$ (by cement weight) of methylcellulose to improve fibre dispersion in the paste. The highest percentage of this type of fibre used was 3\% due to the difficulty in obtaining homogeneous mortars with larger proportions, even when methylcellulose was added.

While the addition of fibres of this length might initially be expected to enhance flexural strength, that was not the case. Strength in fact declined when the percentage of fibre was increased. The reason may possibly be that the fibres curve, reducing their interaction with the paste and, therefore, the intrinsic strength of the whole. In any event, the decline is not regarded to be significant.

The compressive strength of AAS mortars made with 0 , 1 and 3\% CF3 and 0.4\% methylcellulose is plotted against curing time in Figure $6 b$. The results were observed to be similar to the findings for flexural strength behaviour: the strength of the addition-containing mortars dipped with respect to the control, but the decline was not statistically significant.

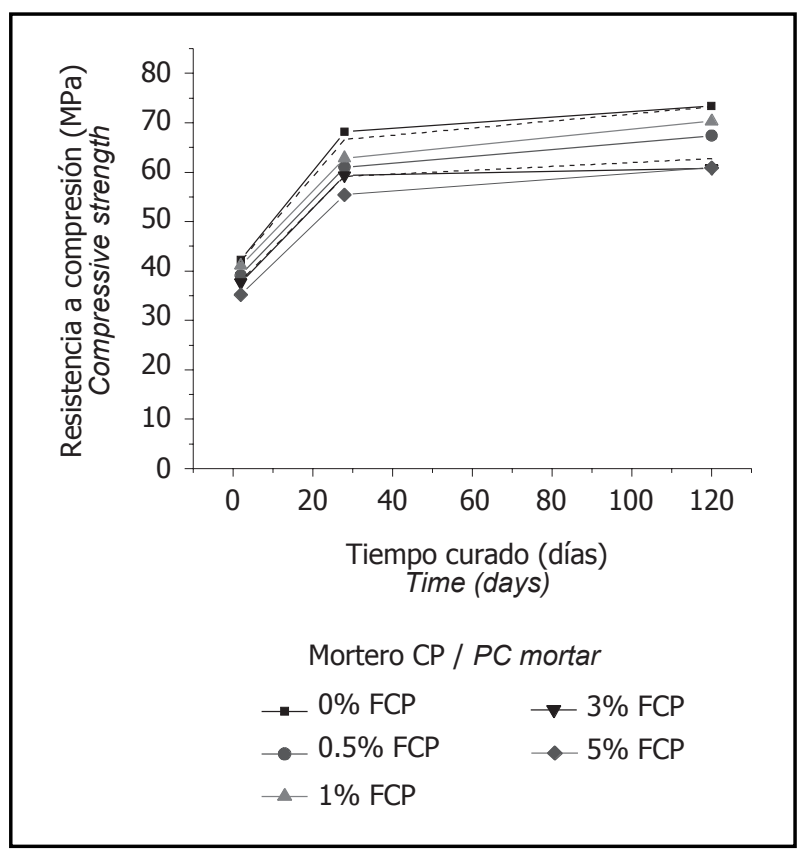

Figura 5. Resistencia a compresión en función del tiempo de curado de morteros de CP fabricados con adición de distintos porcentajes de FCP. (Las líneas discontinuas representan el intervalo de confianza del $95 \%$.)

Figure 5. Compressive strength versus curing time in $C P$ mortars made with different percentages of CFP.

(The dotted lines denote the 95\% confidence intervals.) 


\subsection{Retracción}

Los resultados obtenidos se muestran en la Figura 7. Como era de esperar, los morteros de CP tienen una retracción al secado alrededor de 3-4 veces menor que los correspondientes de AAS. Las causas de la mayor retracción en los morteros de AAS se deben a la naturaleza de los productos de reacción formados (principalmente un gel $\mathrm{CSH}$, con una baja relación $\mathrm{C} / \mathrm{S}$ ) y a la mayor meso y microporosidad de estos materiales $(14,25)$.

Si observamos el efecto de la relación líquido/sólido en la retracción al secado de los morteros de AAS sin adición de fibra, comprobamos que cuando se incrementa dicha relación, la retracción disminuye. Una explicación a este comportamiento se puede dar porque en los sistemas cementantes, cuanto mayor es la relación líquido/sólido, mayor es la porosidad total y el tamaño de sus poros. Este incremento en el tamaño de poros produce una disminución en la tensión capilar cuando se elimina el líquido que contienen.

El efecto de la fibra de carbón sobre la retracción al secado en estos morteros varía dependiendo del tipo de ligante. En el caso de los morteros de CP, no afecta ni positiva ni negativamente a la retracción; sin embargo, en los morteros de AAS el efecto es diverso. Cuando la relación líquido/sólido es de 0,5 , la incorporación de la fibra de carbón tiene un claro efecto positivo, disminuyendo la retracción según se incrementa el contenido de fibra en el mortero,

\subsection{Shrinkage}

The results obtained are shown in Figure 7. As expected, drying shrinkage was around three to four times lower in the PC than in the AAS mortars. The greater shrinkage in AAS mortars is due to the nature of the reaction products formed (primarily a $\mathrm{CSH}$ gel with a low C/S ratio) and the greater meso- and microporosity in these materials $(14,25)$.

When the liquid/solid ratio is increased in AAS mortars without fibre additions, drying shrinkage declines. A possible explanation for this behaviour is that in cementitious systems, the higher the liquid/solid ratio the greater is total porosity and pore size. This increase in pore size lowers capillary tension when the liquid is eliminated.

The effect of carbon fibre on drying shrinkage in these mortars varies with the type of binder. In PC mortars, shrinkage is unaltered by the fibre, while in AAS the effect is variable. When the liquid/solid ratio is 0.5 , the inclusion of carbon fibre has a clearly beneficial effect, as shrinkage declines by up to $50 \%$ with rising proportions of fibre. When the liquid/solid ratio is 0.56 , shrinkage declines when the fibre content is low, but shoots
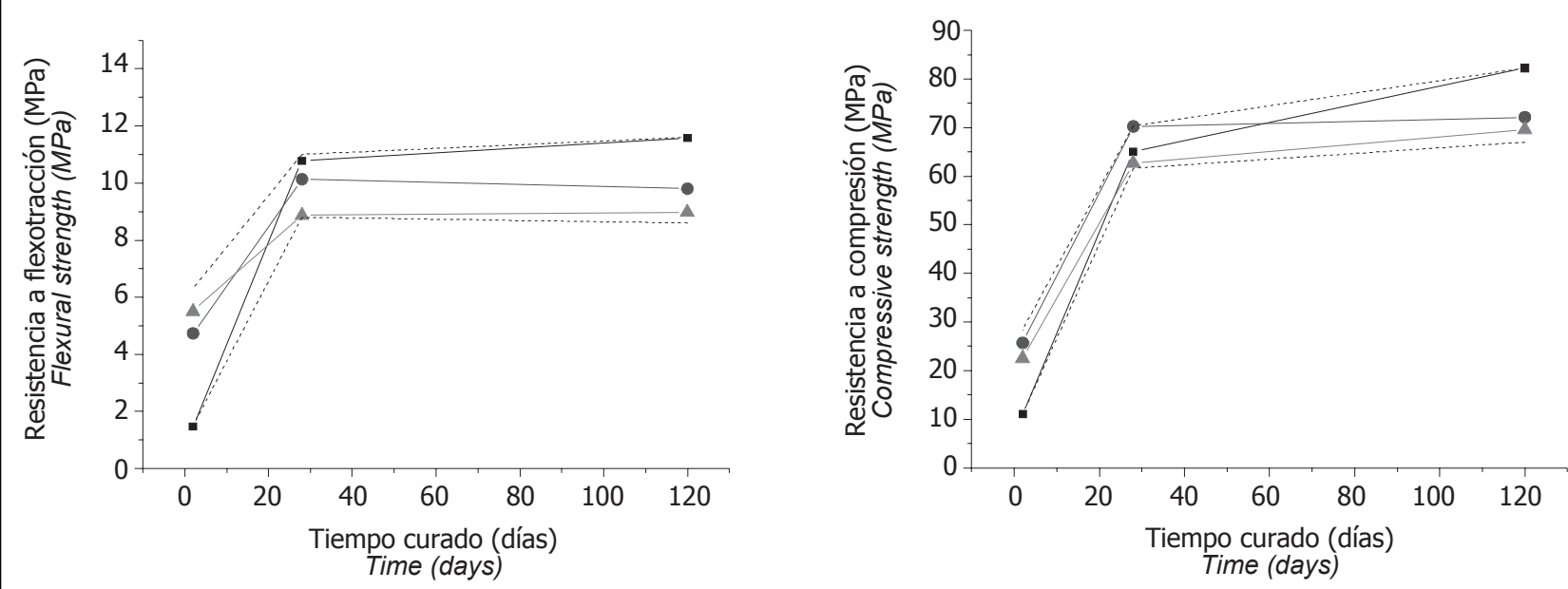

Mortero ASS / ASS mortar

$-0 \% \mathrm{FC} 3$

- $1 \%$ FC3

$-3 \%$ FC3

Mortero ASS / ASS mortar

$-0 \% \mathrm{FC} 3$

$-1 \%$ FC3

$-\mathbf{- 1}-3 \% \mathrm{FC} 3$

Figura 6. Resistencia a flexotracción y compresión en función del tiempo de curado de morteros de AAS fabricados con adición de distintos porcentajes de FC3. (Las líneas discontinuas representan el intervalo de confianza del $95 \%$.)

Figure 6. Flexural and compressive strength versus curing time in AAS mortars made with different percentages of CF3. (The dotted lines denote the $95 \%$ confidence intervals.) 
alcanzando una reducción cercana al 50\%. Cuando la relación líquido/sólido es de 0,56 , la retracción disminuye con bajos contenidos en fibra, pero se dispara cuando el porcentaje de fibra incorporado es del 3\%. Este resultado es difícil de explicar, y puede ser motivado en parte por la elevada heterogeneidad que se produce en el sistema y que podría explicar a su vez la disminución observada en las resistencias mecánicas.

Las fibras de carbón no modifican el comportamiento de los morteros de CP respecto a su estabilidad de volumen.

\subsection{Nivel de corrosión de armaduras embebidas en los morteros estudiados}

Los morteros de AAS que se han fabricado para el estudio de corrosión (y también para el de resistencias mecánicas) se han realizado con dosificación disolución activadora/escoria de 0,56 por ser ésta la que por un lado ofrece la mejor trabajabilidad, aunque también, como hemos descrito anteriormente, la mayor retracción al secado. De esta manera se plantea el estudio de características resistentes y nivel de corrosión en el caso más desfavorable.

La Figura 8 muestra la evolución de la velocidad de corrosión frente al tiempo en morteros de AAS con cemento alcalino y distintos porcentajes 0,1 y $3 \%$ de adición de FC3, con relación disolución activadora/escoria de $0,56,0,4 \%$ de metilcelulosa y sometidas a un proceso de carbonatación acelerada. abruptly upward when 3\% fibre is added. This result, difficult to explain, may be partially due to system heterogeneity, which may also be the reason for the decline observed in strength.

Carbon fibres had no effect on PC mortar volume stability.

\subsection{Embedded reinforcement corrosion}

The AAS mortars prepared for the corrosion study (and strength testing) were made with an activating solution/slag ratio of 0.56 , the proportion that afforded greater workability and, as noted above, greater drying shrinkage. In other words, strength and shrinkage were tested under the least favourable conditions.

Figure 8 shows the variation in corrosion rates over time in AAS mortars with alkaline cement and 0, 1 and 3\% CF3, $0.4 \%$ methylcellulose and an activating solution/slag ratio of 0.56, after exposure to accelerated carbonation.

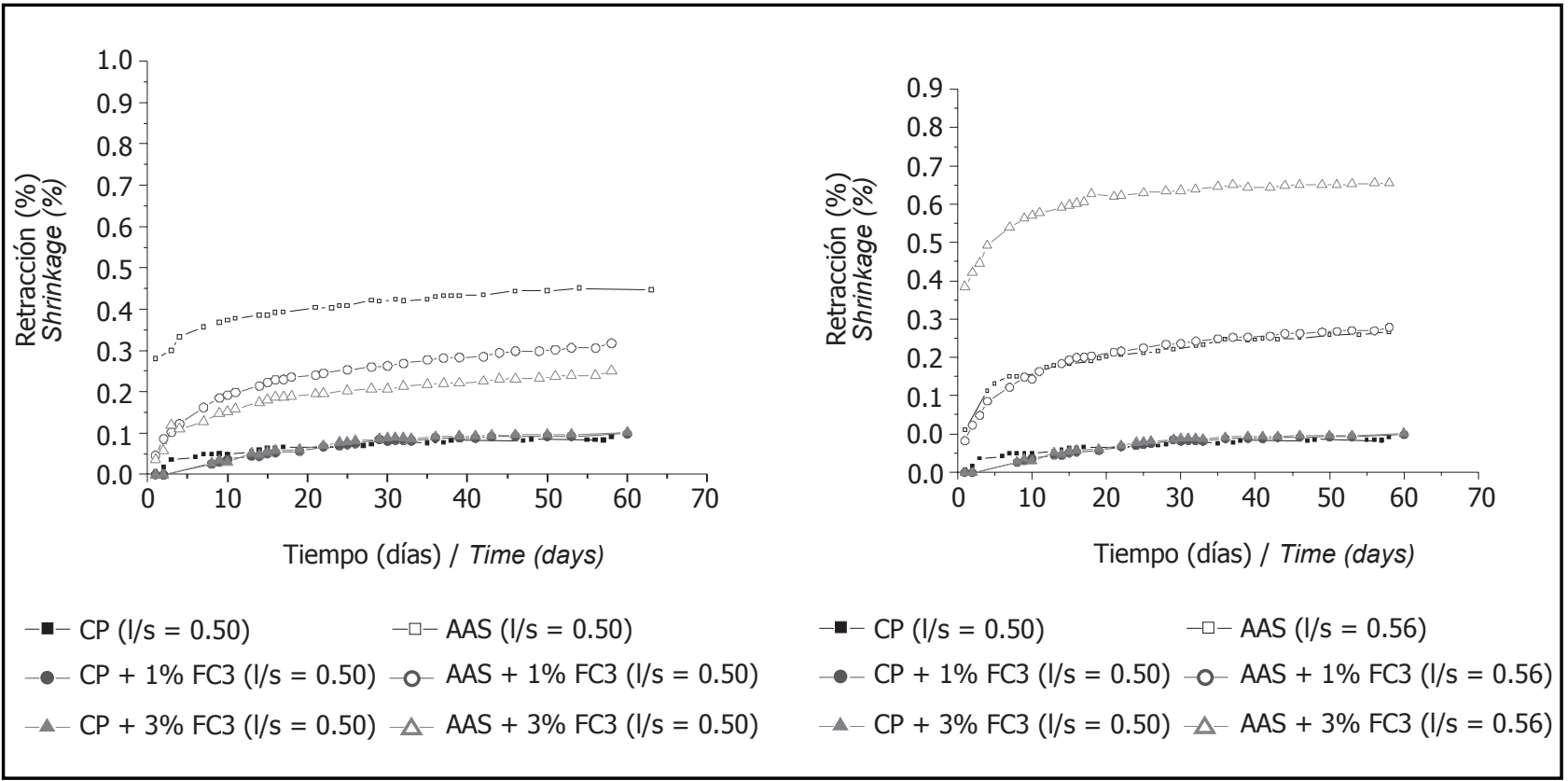

Figura 7. Valores de porcentaje de retracción en función del tiempo de curado de morteros de CP y AAS fabricados con adición de distintos porcentajes de FC3 y adición de 0,4\% de metilcelulosa (líquido/sólido (I/s).)

Figure 7. Shrinkage percentage versus curing time for PC and AAS mortars made with different percentages of CF3 and $0.4 \%$ methylcellulose. (Liquid/solid (I/s).) 
Se puede observar en la misma que durante el proceso de curado, tanto el patrón como la muestra con $1 \%$ de FC3 se pasiva, sin embargo, la muestra con $3 \%$ de FC3 no llega, sorprendente, a pasivarse. El proceso de carbonatación implica que todos los morteros estudiados sitúan sus niveles máximos de corrosión en $3,2 \mu \mathrm{A} / \mathrm{cm}^{2}$, $4,8 \mu \mathrm{A} / \mathrm{cm}^{2}, 5,7 \mu \mathrm{A} / \mathrm{cm}^{2}$ para el patrón, $1 \%$ FC3 y $3 \%$ FC3, respectivamente. Tras un periodo de tiempo en torno a 50 días, se estabilizan los valores en 0,7 $\mu \mathrm{A} / \mathrm{cm}^{2}, 1,4 \mu \mathrm{A} / \mathrm{cm}^{2}, 2,5 \mu \mathrm{A} / \mathrm{cm}^{2}$, respectivamente. Por tanto, análogamente a lo observado en morteros con cemento Portland, la carbonatación implica el desarrollo de la pila de corrosión y la cinética de la misma viene incrementada por la presencia de materiales carbonosos (18).

En estudios precedentes $(26,27)$ se ha comprobado que la velocidad de carbonatación de las pastas y morteros de AAS es superior a la que experimentan los correspondientes de CP. Esto se debe a que en los materiales alcalinos la interacción entre el $\mathrm{CO}_{2}$ disuelto en la fase acuosa del sistema poroso y las fases sólidas de las pastas ocurre directamente sobre el gel $\mathrm{CSH}$; mientras en los sistemas de CP la interacción es inicialmente sobre la portandita y, posteriormente, sobre el gel CSH, cuando la primera se ha consumido totalmente.

La Figura 9 muestra la evolución de la velocidad de corrosión en morteros de AAS y distintos porcentajes 0 , 1 y $3 \%$ de adición de FC3, con relación disolución activadora/escoria de 0,56, y sumergidas parcialmente en agua de mar.

En primer lugar, es importante destacar el comportamiento del patrón que durante todo el periodo de medida presenta valores de $I_{\text {corr }}$ inferiores a $0,1 \mu \mathrm{A} / \mathrm{cm}^{2}$, manteniendo por tanto su pasividad a pesar del ambiente agresivo. Este comportamiento es coherente con el menor nivel de difusión de cloruros en estos cementos observado por otros autores (6). Por otra parte, la presencia de un 1\% de FC3 no implica tampoco la despasivación clara de la armadura, puesto que la medida de $I_{\text {corr }}$ se estabiliza en torno a un valor medio de 0,1 $\mu \mathrm{A} / \mathrm{cm}^{2}$. Por el contrario, la presencia de un $3 \%$ de FC3 sí implica el desarrollo de la pila de corrosión por ataque por cloruros, situándose el valor medio en torno 2 $\mu \mathrm{A} / \mathrm{cm}^{2}$.

Se puede observar que el aumento del contenido de material carbonoso implica un aumento del nivel de corrosión del refuerzo. Ahora bien, contrariamente a lo que ocurre cuando las probetas se someten a un proceso de carbonatación acelerada donde incluido el patrón experimentan un proceso de corrosión similar al del cemento Portland, ante un ataque por cloruros, no se muestra vulnerable frente al mismo manteniendo la
Note that during the curing process both the control and the sample with 1\% CF3 were passivated while the 3\% sample, surprisingly, was not. The maximum corrosion levels reached in the carbonation process came to 3.2 $\mu A / \mathrm{cm}^{2}, 4.8 \mu \mathrm{A} / \mathrm{cm}^{2}$ and $5.7 \mu \mathrm{A} / \mathrm{cm}^{2}$ for the control, $1 \%$ CF3 and 3\% CF3 respectively. After around 50 days these values flattened at $0.7 \mu \mathrm{A} / \mathrm{cm}^{2}, 1.4 \mu \mathrm{A} / \mathrm{cm}^{2}$ and 2.5 $\mu A / \mathrm{cm}^{2}$, respectively. Consequently, as in Portland cement mortars, carbonation involves the development of the corrosion cell, whose kinetics are enhanced by the presence of carbonaceous materials (18).

Prior studies $(26,27)$ showed that the carbonation rate is higher in AAS than in the respective $P C$ pastes and mortars. This is because in alkaline materials the interaction between the $\mathrm{CO}_{2}$ dissolved in the aqueous phase of the porous system and the solid phases of the pastes takes place directly on the CSH gel, whereas in PC systems this interaction occurs initially on the portlandite and after that substance is entirely depleted, on the $\mathrm{CSH}$ gel.

Figure 9 shows the variation in corrosion rate in $A A S$ mortars with 0, 1 and 3\% CF3 and an activating solution/slag ratio of 0.56 , partially submerged in seawater.

Attention should first be drawn to the behaviour of the control, with $I_{\text {corr }}$ values of under $0.1 \mu \mathrm{A} / \mathrm{cm}^{2}$ throughout: i.e., the steel maintains its passivity despite the aggressive environment. This behaviour is consistent with the lower diffusion of chlorides in such cements observed by other authors (6). Moreover, the presence of $1 \%$ CF3 entailed no clear depassivation of the reinforcement, for the $I_{\text {corr }}$ measurement stabilized at a mean value of around $0.1 \mu \mathrm{A} / \mathrm{cm}^{2}$. The presence of $3 \% \mathrm{CF} 3$, on the contrary, led to the development of the chloride-induced corrosion cell, with the mean $I_{\text {corr }}$ value hovering around $2 \mu \mathrm{A} / \mathrm{cm}^{2}$.

Corrosion levels were higher in the presence of larger amounts of carbonaceous material. However, contrary to their behaviour when exposed to accelerated carbonation, where even in the control corrosion was similar to the process observed in Portland cement, the AAS specimens proved to be invulnerable to chloride attack and to maintain their passivity. This feature makes such cements particularly suitable for marine environments. 


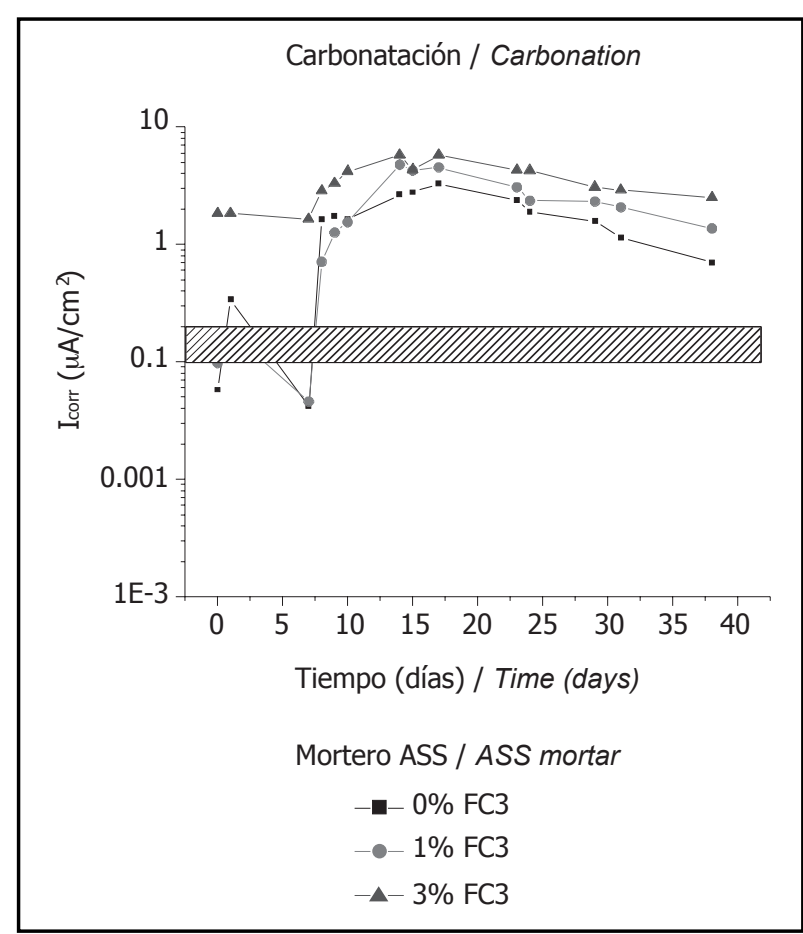

Figura 8. Evolución de la velocidad de corrosión en morteros de AAS y distintos porcentajes de adición de FC3, sometidos a un proceso de carbonatación acelerada.

Figure 8. Evolution in corrosion rate in AAS mortars with different percentages of CF3, exposed to accelerated carbonation.

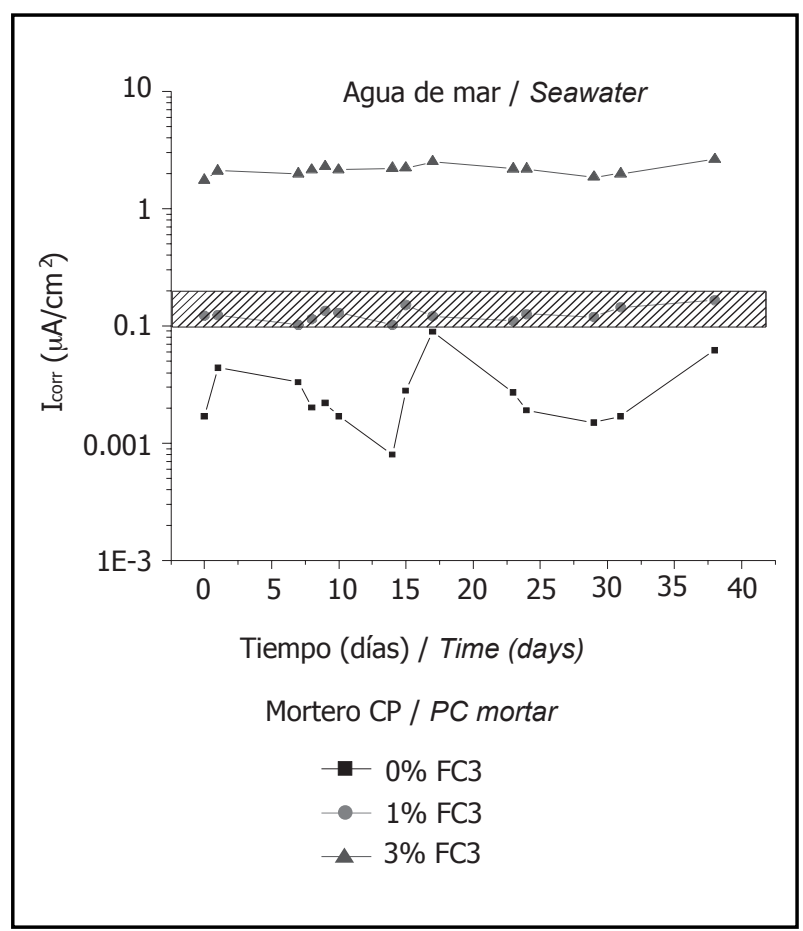

Figura 9. Evolución de la velocidad de corrosión en morteros de AAS y distintos porcentajes de FC3, con relación disolución activadora/escoria de 0,56, y sumergidas parcialmente en agua de mar.

Figure 9. Evolution in corrosion rate in AAS mortars containing different percentages of CF3 and an activating solution/slag ratio of 0.56 , partially submerged in seawater.

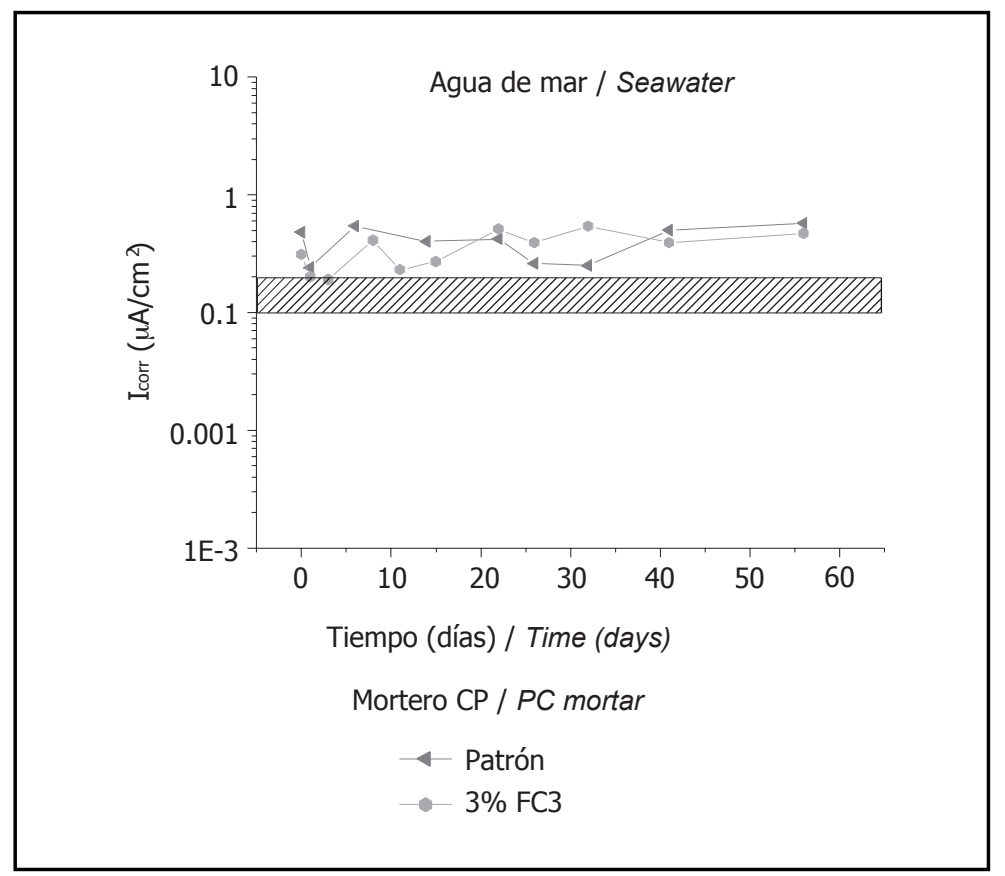

Figura 10. Evolución de la velocidad de corrosión frente al tiempo en morteros de CP con distintos porcentajes de adición de FC3 y sumergidos parcialmente en agua de mar.

Figure 10. Variation in corrosion rate over time in PC mortars containing different percentages of CF3 and partially submerged in seawater. 
pasividad, lo cual implicaría un interés adicional de cara a su uso en ambientes marinos. Distinto es el comportamiento del mortero de CP con este mismo tipo de fibra que presenta un nivel de corrosión elevado desde el inicio de la inmersión en agua de mar, ver Figura 10. Los iones $\mathrm{OH}^{-}$y los iones $\mathrm{Cl}^{-}$presentes en la interfase compiten entre ellos: los primeros por su acción pasivante y los segundos por su acción despasivante. La proporción que haya entre ellos marcará finalmente el resultado. El mayor nivel de alcalinidad que caracteriza la disolución intersticial de los cementos alcalinos explica el resultado obtenido.

A la hora de explicar y discutir el diferente comportamiento que han mostrado los aceros embebidos en morteros de AAS con diferentes porcentajes de FC3 hay que considerar que la adición de estos materiales conductores, en cantidades crecientes, implica un descenso progresivo de la resistividad del hormigón. Por otra parte, dado que los materiales carbonosos poseen una naturaleza más noble que el acero, ejercen un efecto de par galvánico sobre el mismo. Ambos hechos contribuyen al desarrollo de la pila de corrosión, es decir, a un aumento de los valores de $\mathrm{I}_{\text {corr }}$ registrados al aumentar el porcentaje de FC3 añadido. En los morteros de cemento Portland, más vulnerable, la acción de los cloruros enmascara este mecanismo.

\section{CONCLUSIONES}

De la evaluación de los datos experimentales se pueden establecer las siguientes conclusiones:

1. La adición de fibra de carbón, independientemente de su longitud (FCP o FC3), a morteros de AAS, en general, no modifica significativamente las características resistentes de los mismos con respecto al patrón. Para los morteros $\mathrm{CP}$, la adición de porcentajes superiores al $3 \%$ de fibra disminuye significativamente sus características resistentes.

2. El efecto de la fibra de carbón FC3 sobre la retracción al secado de los morteros que las contienen depende del tipo de ligante:

2a. Para morteros de AAS con relación líquido/sólido de 0,5 , la incorporación de la fibra de carbón tiene un claro efecto positivo, disminuyendo la retracción según se incrementa el contenido de fibra en el mortero, alcanzando una reducción cercana al $50 \%$.

2b. La incorporación de la fibra FC3 a morteros de CP no altera su estabilidad de volumen.

3. La presencia de fibra de carbón en morteros de AAS sometidos a un proceso de carbonatación incrementa
By contrast, PC mortar reinforced with the same type of fibre exhibited high corrosion levels soon after immersion in seawater (see Figure 10). The competing $\mathrm{OH}^{-}$and $\mathrm{Cl}^{-}$ ions present at the interface passivate and depassivate the embedded steel, respectively. The end result is determined by the proportion between the two. The above findings can be attributed to the greater alkalinity that characterizes the interstitial solution in alkaline cements.

Any explanation or discussion of the differences in the behaviour of the steel embedded in AAS mortars containing different percentages of CF3 should take account of the following: the addition of these conductive materials in increasing proportions entails a progressive decline in concrete resistivity. At the same time, given that the carbonaceous materials are nobler than steel, they exert a galvanic couple effect on the metal. These two factors contribute to the development of the corrosion cell, i.e., to a rise in the $I_{\text {corr }}$ values recorded when the percentage of CF3 added is increased. In the more vulnerable Portland cement mortars, chloride action masks this mechanism.

\section{CONCLUSIONS}

The conclusions to be drawn from the experimental data are as follows:

1. Generally speaking, the addition of carbon fibre, regardless of length (CFP or CF3), to AAS mortars does not significantly alter their strength, while the addition of over $3 \%$ of fibre to PC mortars lowers their strength significantly.

2. The effect of CF3 carbon fibre on mortar drying shrinkage depends on the type of binder:

2a. For AAS mortars having a liquid/solid ratio of 0.5, the inclusion of carbon fibre has a clearly beneficial effect, as shrinkage declines by up to $50 \%$ with rising proportions of fibre.

2b. The addition of CF3 fibre to PC mortars does not alter their volume stability.

3. The presence of carbon fibre in AAS mortars exposed to accelerated carbonation raises the corrosion levels 
el nivel de corrosión del acero embebido en el mismo, tanto más cuanto mayor sea su proporción.

4. La adición del $1 \%$ de fibra de carbón a morteros de AAS, presenta un comportamiento excelente frente a la corrosión ante un ataque por cloruros, manteniéndose pasivadas las armaduras durante todo el tiempo de experimentación. of the embedded steel, more intensely with higher proportions of fibre.

4. The addition of $1 \%$ carbon fibre to AAS mortars enhances their resistance to chloride-induced corrosion, with reinforcement passivity remaining unaltered through the end of the experiment.

\section{BIBLIOGRAFÍA / BIBLIOGRAPHY}

(1) Purdon, A. O.: "The action of alkalis on blast-furnace slag", Journal of the Society of Chemical Industry, 59 (1940), pp. 191-202.

(2) Glukhovskij, V.; Zaitsev, Y. y Pakhomow, V.: "Slag-alkaline cements and concrete-structures, properties, technological and economical aspects of the use", Silicates Industriels, 10 (1983), pp. 197-200.

(3) Glukhovskij, V.; Rostowkaja, G. S. y Rumyna, G. V.: "High strength slag-akali cement", VII ICCC (París) (1980), vol. III, V-164-168.

(4) Puertas, F.; Gutierrez, R. de; Fernández-Jiménez, A.; Delvasto, S. y Maldonado, J.: "Morteros de cementos alcalinos. Resistencia química al ataque por sulfatos y agua de mar", Mater. Construcc., vol. 52, n० 267 (2002), pp. 55-71.

(5) Byfors, K.; Klingstedt, G.; Lehtonen, V.; Pyy, H. y Romben, L.: "Durability of concrete made with alkali-activated slag", $3^{\text {rd }}$ Inter. Conf. on fly-ash, silica fume, slag and natural pozzolans in concrete (Norway), vol. 2 (1989), pp. 1429-1466.

(6) Deja, J. y Malolepszy, J.: "Resistance of alkali-activated slag mortars to chlorine solution", $3^{\text {rd }}$ Inter. Conf. on fly-ash, silica fume, slag and natural pozzolans in concrete (Norway), vol. 2 (1989), SP 114-75, pp. 1547-1563.

(7) Bakharev, T.; Sanjayan, J. G. y Cheng, Y. B.: "Resistance of alkali-activated slag concrete to acid attack", Cem. Concr. Res., vol. 33 (2003), pp. 1607-1611.

(8) Puertas, F.; Amat, T.; Fernández-Jiménez, A. y Vázquez, T.: "Mechanical and durable behaviour of alkaline cement mortars reinforced with polypropylene fibres", Cem. Concr. Res., vol. 33 (2003), pp. 2031-2036.

(9) Krivenko, P. V.: "Alkaline cements and concretes: problems of durability", $2^{\text {nd }}$ Intern. Conf. Alkaline Cements and Concretes (Kiev), 1999, pp. 3-43.

(10) Gutiérrez, R. de; Maldonado, J. y Gutiérrez, C.: "Resistencia a temperaturas elevadas de escorias activadas alcalinamente", Mater. Construcc., vol. 54, no 276 (2004), pp. 87-92.

(11) Fernández-Jiménez, A.; Puertas, F.; Sobrados, I. y Sanz, J.: "Structure of calcium silicate hydrates formed in alkaline-activated slag: Influence of the type of alkaline activator", J. Am. Ceram. Soc., 86 (8) (2003), pp. 1389-1394.

(12) Escalante-García, J. I.; Fuentes, A. F.; Gorokhovsky, A.; Fraile-Luna, P. E. y Mendoza-Suárez, G.: "Hydration products and reactivity of blast-furnace slag activated by various alkalis", J. Am. Ceram. Soc., 86 (12) (2003), pp. 2148-2153.

(13) Collins, F. y Sanjayan, J. G.: "Effect of pore size distribution on drying shrinkage of alkali-activated slag concrete", Cem. Concr. Res., vol. 30 (2000), pp. 1401-1406.

(14) Palacios, M. y Puertas, F.: "Effect of shrinkage-reducing admixtures on the properties of alkali-activated slag mortars and pastes", Cem. Concr. Res., vol. 37 (2007), pp. 691-702.

(15) Puertas, F.; Amat, T. y Vázquez, T.: "Comportamiento de morteros de cementos alcalinos reforzados con fibras acrílicas y de polipropileno", Mater. Construcc., vol. 50, no 259 (2000), pp. 69-84.

(16) Puertas, F.; Gil-Maroto, A.; Palacios, M. y Amat, T.: "Alkali-activated slag mortars reinforced with AR glas fibre. Performance and properties". Mater. Construcc., no 283, 79-90 (2006).

(17) Lin, S.: "Application of short carbon-fiber in construction", Sample Journal, 30 (5) (1995), pp. 39-45.

(18) Garcés, P.; Fraile, J.; Vilaplana-Ortego, E.; Cazorla-Amorós, D.; Alcocel, E. G.a y Andión, L. G.a: "Effect of Carbon fibers on the mechanical properties and corrosion levels of Portland cement mortars", Cem. Concr. Res., 35 (2005), pp. 324-331.

(19) Garcés, P.; Andión, L. G.a; Catalá, G.; Varga, I. de la y Zornoza, E.: "Corrosion of steel reinforcement in structural concrete with carbon material addition", Corrosion Science., vol. 49 (2007), pp. 2557-2566.

(20) Sugama, T.; Kukacka, L. E.; Carciello, N. y Gallen, B.: "Oxidation of carbon fiber surfaces for improvement in fiber-cement interfacial bond at a hidrothermal temperature of $300^{\circ} \mathrm{C}^{\prime}$, Cem. Concr. Res., 18 (2) (1988), pp. 290-300.

(21) UNE-EN-196-1: Métodos de ensayos de cementos. Parte 1: determinación de resistencias mecánicas.

(22) UNE-80112:1989 ex: Métodos de ensayo de cementos. Ensayos físicos. Determinación de la retracción de secado y de linchamiento en agua.

(23) Stern, M. y Geary, A. L.: "A theorical analysis of the shape of polarization curves", J. Elect. Soc., vol. 104, no 1 (1957), p. 56.

(24) Stern, M. y Weisert, E. D.: "Experimental observations on the relation between polarization resistance and corrosion rate", Proc. Am. Soc. Test. Mater, vol. 59 (1959), pp. 1280.

(25) Palacios, M.: Efecto de aditivos orgánicos en las propiedades y comportamiento de pastas y morteros de escorias activadas alcalinamente. Tesis Doctoral. Universidad Autónoma de Madrid, 2006. 
(26) Puertas, F.; Palacios, M. y Vázquez, T.: "Carbonation process on alkali-activated slag mortars", Journal of Material Science, 41 (2006), pp. 3071-3082.

(27) Palacios, M. y Puertas, F.: "Alkali-activated slag cements. Process and mechanisms of carbonation", Journal of American Ceramic Society, 89, 10 (2006), pp. 3211-3221.

\section{Fe de erratas}

En el número 287, correspondiente al periodo julio-septiembre de 2007, y por un error de impresión, el nombre de uno de los autores del artículo "Desarrollo de mezclas de hormigón poroso para pavimentos urbanos permeables" es H. de Solminihac y no H. de Solominihac, como aparece publicado. Pedimos disculpas por el error, y en la versión electrónica disponible en http://materconstrucc.revistas.csic.es el error ha sido subsanado.

Además en el mismo trabajo, se omitió la línea de división entre divisor y dividendo en la ecuación 3.

In the July-September issue of the journal (287), the name of one of the authors of the article titled "Porous concrete mixtures for pervious urban pavements" was misprinted: the correct spelling is $\mathrm{H}$. de Solminihac, not $\mathrm{H}$. de Solominihac as it appeared. We apologize for this error, which has been corrected in the on-line version available on: http://materconstrucc.revistas.csic.es

In the same paper, in equation 3, the line between the divisor and dividend was omitted. 